\title{
TYPES OF MEDIA AND TEACHING TECHNIQUES IN TEACHING SPEAKING AT SMP BRAWIJAYA SMART SCHOOL MALANG
}

\author{
(Tipe-Tipe Media dan Teknik Pengajaran dalam Pengajaran Berbicara \\ di SMP Brawijaya Smart School)
}

\author{
Muh. Rajib Silmi \\ Magister Linguistik, University of Brawijaya Malang \\ Jalan Veteran, Malang, Jawa Timur 65145, Indonesia \\ Pos-el: m_rajibsilmi@yahoo.com
}

\begin{abstract}
The aims of this research is to find out the teaching techniques and media used by the English teacher in teaching speaking to the seventh-grade students at SMP Brawijaya Smart School Malang. This is a case study research design. Instruments of this research are observation sheets, interview guides and documentation. The researcher observes all of the English teaching processes at the seventh-grade class. The researcher also interviews teachers and five students to get additional information. The documentation is used to confirm the data from observation. The result of the research shows that the English teachers use various teaching techniques namely question-answer display, translation, drilling, and discussion. The English teachers also use various teaching media namely human, printed, visual media and multimedia. However, the English teachers mostly use the question-answer display as teaching technique and printed media as the teaching media. Most students are interested in teaching techniques and the teaching media used by the teacher in teaching speaking. Based on the finding, the researcher has several suggestions for the English teacher and also for a further researcher. For the English teacher at SMP Brawijaya Smart School, the researcher suggests the teachers keep good things of teaching techniques and teaching media because the techniques are interesting. However, it will be better if the English teacher can give other teaching techniques and teaching media. Besides, it can also give the other views of the English teacher on teaching technique and teaching media. For further researchers, the study with a similar topic, the researcher suggests further researchers explore on more specific focus dealing with teaching technique or teaching media by conducting a research on more specific focus, it can be analyzed more deeply.
\end{abstract}

Keywords: teaching speaking, teaching technique, teaching media

\begin{abstract}
Abstrak: Penelitian ini bertujuan untuk mengetahui teknik dan media mengajar berbicara Bahasa Inggris pada siswa kelas tujuh di SMP Brawijaya Smart School Malang. Penelitian ini merupakan penelitian studi kasus. Instrumen yang digunakan dalam penelitian ini berupa lembar observasi, wawancara, dan dokumentasi. Hasil penelitian menunjukkan bahwa guru bahasa Inggris menggunakan berbagai macam teknik dan media pengajaran, antara lain teknik tanya jawab, teknik penerjemahan, teknik pengulangan, teknik diskusi, manusia sebagai media, media cetak, media visual, dan multimedia. Namun, guru seringkali menggunakan teknik tanya jawab sebagai teknik mengajar dan media cetak sebagai media mengajar. Berdasarkan hasil interview, kebanyakan siswa tertarik dengan teknik dan media mengajar yang digunakan oleh guru bahasa Inggris. Berdasarkan hasil tersebut, peneliti menyarankan guru bahasa Inggris di SMP Brawijaya Smart School untuk menjaga keunggulan dalam pengunaan teknik dan media yang digunakan karena menarik bagi siswa. Namun, hal tersebut akan lebih baik jika guru menggunakan lebih banyak variasi teknik dan media pengajaran agar bisa memberikan lebih banyak pengetahuan. Selain itu, untuk peneliti selanjutnya yang melakukan penelitian dengan topik yang hampir sama, peneliti menyarankan untuk mengembangkan fokus penelitian yang lebih mendalam agar bisa dianalisis secara mendalam
\end{abstract}

Kata Kunci: pengajaran berbicara, teknik mengajar, media mengajar 


\section{INTRODUCTION}

Technique and media in teaching are needed by teachers. Nurhayati (2012) stated that appropriate technique and media chosen by the teachers in teaching process can lead students to achieve the goal of learning. Teaching technique helps both the teachers and students in teaching and learning process, especially to encourage students' ability in learning. Meanwhile, teaching media helps the teachers in presenting material when teaching and learning process is conducted.

Teaching technique can help both teachers and students in teaching speaking process, especially to encourage students' ability and understanding the material given. Indriyani (2015) stated that teaching technique is one of the ways for students to understand English. Teaching technique can be as a supporting detail for the English teachers to reach lesson objectives. Based on Crookes and Chaudron (1991), teaching technique are divided into three categories, namely controlled, semi controlled and free. Crookes and Chaudron (1991) stated that controlled technique is when a teacher has controlled over teaching process. Controlled technique category is a basic teacher-centered; the way teacher controlled teaching and learning process. In controlled technique, there are many techniques that can be used in teaching process such as warm up, setting, organizational, content explanation, role play demonstration, dialogue or narrative presentation and recitation, reading aloud, checking, question-answer display, drill, translation, dictation, copying, identification, recognition, review, testing, and meaningful drill. Then, semi controlled category covers brainstorming, storytelling, questionanswer referential, cued narrative or dialogue, information transfer, information exchange, wrap-up, narration or exposition, and preparation. Free category is focusing on student centered. It covers role-play, games, report, problem solving, drama, simulation, discussion, composition, and a propos. Hence, controlled technique is a teacher centered; semi controlled is role of combination between the teacher and students, free technique is a student centered. From those three categories, the researcher took some techniques from each category because those techniques can be used in teaching speaking process, such as discussions, role play, simulation, brainstorming, storytelling, and games. Kayi (2006) stated that discussions, role play, simulation, brainstorming, and storytelling are the techniques for teaching speaking.

Teaching media helps teacher in conducting teaching and learning activity in the class. It makes teacher easier in delivering knowledge during teaching process. However, before using the media, the teachers should know whether the media is useful or not. Bertram, Ranby, Adendorff, Reed, and Roberts, (2010) stated that the teachers need to understand how media resource can be useful within learner-centered. The teachers should choose the media that will be used in teaching and learning based on material needs in order to reach the goal of learning. Moreover, media offers positive contributions towards teaching and learning process. Nowadays, there are many kinds of media that can be used in teaching and learning process. Arsyad (2015) stated that there are six categories of teaching media such as human media, printed media, audio media, visual media, audio-visual media, and multimedia. Those six categories of media can be used in teaching and learning process especially in a scope of English teaching and learning process. Human media is also part of teaching media. Arsyad (2015) stated that human as media is the oldest media that is still used to deliver the knowledge.

Further, in language teaching process, language teachers especially the English teachers, can guide other people (students) to be able to speak fluently with the 
technique and media they have as role of a teacher. Indriyani (2015) stated that the teachers have important role in succeeding students in speaking. However, before using appropriate technique and media in teaching process, the English teachers need to make their students understand that they also need to know what is required in speaking a foreign language. Khameis (2006) stated that learning to speak a foreign language requires more than understanding grammar and vocabulary. It also requires the function of language.

As a foreign language in Indonesia, it is important that English should be taught at the seventh grade. Students at the seventh grade are also called late childhood. Pradana (2012) stated that a kid in late childhood phase is started to think critically, they want to show their ability in public. To teach the seventh grade students, the English teachers should have a good technique, good teaching media, and also good skills in teaching. Reed (2003) concluded that there are three general skills for the teachers they should have such as knowledge of what is to be taught, an understanding of how people learn what is to be taught, the ability to convey knowledge and skill from the teacher to students. Those three general skills should be studied by the English teachers before teaching them. If the English teachers have those three general skills, teaching technique, and teaching media, it will make teacher easier to teach the seventh grade students.

While talking about teaching technique, teaching media, and general skills of teaching, the English teachers of SMP Brawijaya Smart School has those three important things (technique, media, and general skills) in teaching. With teaching technique and teaching media used by the English teachers, they guide their students to get achievements. As the evidence, in 2015, after the researcher conducted interview with the English teacher, some students at SMP Brawijaya
Smart School became the winners in many competitions such as first winner in Speech Content Competition in Malang, first winner in Story Telling Competition in Malang, second winner in News Reading Competition in Malang, and runner up in English Debate Competition in Surabaya. For academic score, almost all of the students passed the minimum score (78) in SMP Brawijaya Smart School.

In this research, the researcher focused on teaching techniques and teaching media in teaching speaking at SMP Brawijaya Smart School focusing on teaching speaking skill. The researcher chose SMP Brawijaya Smart School because it has a score for accreditation and got many achievements which meant SMP Brawijaya Smart School is a well-known school. Therefore, the researcher was interested in conducting the research entitled "Technique and Media in Teaching Speaking of the Seventh Grade Students at SMP Brawijaya Smart School Malang".

\section{METHOD}

This research is a case study. A case study is a part of qualitative research. This research described the phenomena happened in the classroom. The phenomena happened in the classroom refers to the teaching techniques and teaching media used by the English teacher during the English teaching process.

In this research, the researcher followed several steps in conducting the research such as observation, interview, and documentation. Firstly, the researcher used observation sheet to observe the teaching speaking process. The observation focused on teaching technique, teaching media, and students' responses during the teaching speaking process. The observation was conducted in every class in every English teaching process that was A class, B class, $\mathrm{C}$ class, $\mathrm{D}$ class, and $\mathrm{E}$ class. The researcher also used a camera for documentation during the English teaching speaking 
process to check and confirm the result of the observation check list. The observation and documentation was conducted in nine meetings in three weeks because the data was already repeated. Secondly, after observing, the researcher interviewed the English teacher (Ms. Yusi) to get valid information from the English teacher. Third, after interviewing Ms. Yusi, the researcher also interviewed five students of the seventh grade students at SMP Brawijaya Smart School about techniques and media used in teaching speaking to get supporting information based on students' point of view. The researcher interviewed those five students because the teacher only allowed the researcher to interview students who got the highest score in speaking skill based on the English teacher's suggestion.

The researcher conducted the research at SMP Brawijaya Smart School Malang. The researcher chose SMP Brawijaya Smart School because the school has A score for accreditation. Besides, based on the interview on pre-observation, teachers at SMP Brawijaya Smart School have done very well in guiding their students to get many achievements especially in English. As an evidence, in 2015, for non-academic achievements, several students of SMP Brawijaya Smart School became the winner in many competitions such as first winner in Speech Content Competition in Malang, first winner in Story Telling Competition in Malang, second winner in News Reading Competition in Malang, and runner up in English Debate Competition in Surabaya. For academic achievement, almost all of the students passed the minimum score (78) in SMP Brawijaya Smart School.

The researcher observed the process of teaching speaking conducted by the English teacher, namely Mrs Yusi. She teaches all of the seventh graders (104 students). Besides, Mrs Yusi has some special strength as a teacher, such as guiding her students to get achievements, taking in charge of curriculum, and she also got a scholarship from SMP Brawijaya
Smart School to continue her master. Those strengths meant Mrs Yusi has a qualified capability in teaching English.

In analyzing the data, this research used flow or interactive model presented by Miles and Huberman (1994). In this section consists of data reduction, data display, conclusion, and data triangulation. Data reduction was used because the researcher should reduce the data to give the researcher clear understanding about the data based on the objective on the research. In this section, after the data collected through observation, interview, and documentation, the researcher selected important data based on the teaching technique and the teaching media used by the teacher, and also students' response during teaching speaking.

After reducing the data, the researcher displayed the data into two categories (teaching technique and teaching media) in a form of descriptive report. Sugiyono (2014) stated that a conclusion in qualitative research is a result of the research based on the phenomena in the field. From that statement, in this research, after the data reduced and displayed, the researcher concluded the teaching technique and teaching media used by the teacher in teaching speaking. The researcher also concluded students' response based on the teaching and learning process. The researcher's conclusion was in a form of descriptive report. Sugiyono (2014) stated that when the researcher used data triangulation, it means the researcher collect the data from many sources to check validity of the data. In this study, for enhancing the validity of the data, triangulation was done by cross checking the three sources of data. They were the data from the interview with the teacher and five students, the data from the observation, and the data from documentation. Whenever the data collected from all sources were similar, the data was considered true and trustworthy. 


\section{FINDING AND DISCUSSION}

\section{Finding of the Interview}

The researcher interviewed the teacher and five students by using interview guide (see appendix 7 and 13) that had been validated by the expert. The researcher conducted interview nine times with the teacher for five classes (A-E class) because it was based on the time of the observation. The interview with the teacher was on April $26^{\text {th }}, 2016$ (D class and E class), April 27 ${ }^{\text {th }}$, 2016 (E class), May 3 ${ }^{\text {rd }}, 2016$ (D class and E class), May $13^{\text {th }}, 2016$ (D and A class), and May $16^{\text {th }}, 2016$ (B class and C class).

The researcher also interviewed five students from five classes. The researcher only interviewed five students because the English teacher suggested the researcher to conduct an interview to students who got highest score in speaking skill. The interview with the students was on April $27^{\text {th }}, 2016$ (student from E class), May $3^{\text {rd }}$, 2016 (student from D class), May $13^{\text {th }}$, 2016 (student from A class), and May $16^{\text {th }}$, 2016 (student from B class and student from $\mathrm{C}$ class).

\section{Finding of the Interview with the English Teacher}

First, for D class, based on the interview on April $26^{\text {th }}, 2016$, it was found that the English teacher only used question answerdisplay. The English teacher used questionanswer because question-answer made students paid attention to the teacher. The English teacher stated that the students in D class is often make some noisy so questionanswer made them paid attention. The English teacher also used power point and whiteboard as teaching media. The English teacher stated that power point and whiteboard made students paid attention for her. She added that most of the students in D class followed teaching and learning process.

Second, for E class, based on the interview on April $26^{\text {th }}, 2016$, it was found that the English teacher also only used question-answer display. The English teacher stated that question-answer help students to be active in answering the question in English. The English teacher only used textbook as teaching media. She said that textbook that she used was appropriate. She added that all of the students enjoyed the teaching and learning process.

Third, for $\mathrm{E}$ class, based on the finding of the interview on April $27^{\text {th }}, 2016$, the researcher found that the English teacher used question-answer and discussion as teaching technique. The English teacher also used textbook as teaching media. The English teacher stated that she used question-answer and discussion because it can help the students to be active in speaking English.

Fourth, for D class, based on the finding of the interview on May $3^{\text {rd }}, 2016$, the researcher found that the English teacher used question-answer, translation, and also drilling as teaching technique. The English teacher also used textbook and whiteboard as the teaching media. The English teacher used question-answer, translation, and drilling because she wanted the students to be active students. The English teacher also used textbook and whiteboard as media because these media could help and appropriate for students in learning English.

Fifth, for E class, based on the finding of the interview on May $3^{\text {rd }}, 2016$, it was found that the English teacher used question-answer, translation, drilling, textbook, and whiteboard because she wanted the students to be active in speaking. For the response of the students, the English teacher also stated that all of the students in E class followed teaching and learning process.

Sixth, for D class, based on the finding of the interview on May $13^{\text {th }}, 2016$, the researcher found that the English teacher used question-answer and translation as the teaching techniques. The English teacher also used textbook and 
whiteboard as the teaching media. She used question-answer and translation because she wanted the students understand about English. The English teacher also used textbook and whiteboard as teaching media because those media were appropriate and made the students easier to understand English. The English teacher stated that the response of the students was good enough and most of them followed the teaching and learning process.

Seventh, for A class, based on the finding of the interview on May $13^{\text {th }}, 2016$, it was found that the English teacher used question-answer, translation, and textbook. The English teacher used those techniques and media because those techniques and media helped students in understanding English. The English teacher added that the textbook was appropriate for students because the textbook was easy to understand and there are many pictures in the textbook. The response of the students was also good and all of them followed teaching and learning process.

Eighth, for B class, based on the finding of the interview with the English teacher on May $16^{\text {th }}, 2016$, the researcher found that the English teacher only used question-answer as teaching technique. The English teacher also used textbook and whiteboard as teaching media. The English teacher used question-answer and textbook because she wanted the students to follow the teaching and learning process. For the response of the students, the English teacher said that there were some students who did not engage with teaching and learning process.

Ninth, for $\mathrm{C}$ class, based on the finding of the interview with the teacher on May $16^{\text {th }}, 2016$, the researcher found that the English teacher only used questionanswer as teaching technique. The English teacher also used textbook and whiteboard as teaching media. The English teacher stated that she used question-answer, textbook, and whiteboard because she wanted the students to pay attention to the teaching and learning process. The English teacher added that the response of the students was very good, all of the students paid attention to teaching and learning process.

\section{Finding of the Interview with the Students}

First, based on the interview with the student from E class, the researcher found that the teaching technique and teaching media were interesting. The student stated that teaching technique and teaching media used by the English teacher were interesting and appropriate with real-life situation.

Second, based on the finding of the interview with the student from D class, the researcher found that the teaching technique and teaching media were interesting. The student stated that teaching technique and teaching media were interesting and helped them to understand English easier.

Third, based on the finding of the interview with the student from A class, it was found that the teaching techniques and teaching media were interesting. The student in A class stated that the teaching and learning process conducted by the teacher was interesting and funny. The student also stated that the textbook was interesting because there were so many pictures.

Fourth, based on the interview with the student from B class, the researcher found that teaching techniques and teaching media conducted were interesting. The student stated that technique and media used by the teacher were interesting because it made the students enjoy and understand the difficult words.

Fifth, based on the finding of the interview with the student from $\mathrm{C}$ class, the researcher found that teaching techniques and teaching media were interesting. The student stated teaching technique used by the English teacher was very interesting because they can understand English. However, the student also stated that the teaching media used by the teacher were 
not really interesting because the teacher often used textbook.

\section{Finding of the Observation and Documentation}

The researcher observed the English teaching process nine times in five classes. In conducting the observation, the researcher used observation sheet (see appendix) that had been validated by the expert. The observation conducted on April $26^{\text {th }}, 2016$ (D and E class), April 27 $7^{\text {th }}, 2016$ (E class), May $3^{\text {rd }}, 2016$ (D and E class), May $13^{\text {th }}, 2016$ (D and A class), and May $16^{\text {th }}, 2016$ (B and C class). The observation conducted nine times in three weeks (with $\mathrm{D}$ and $\mathrm{E}$ class had three meetings for observation and documentation while $\mathrm{A}$ class, B class, and C class only had one meeting for observation and documentation) because it was based on the English teaching process conducted by the English teacher. The English teacher somehow was busy because she had to attend some workshop meetings so that she could not conduct the English teaching process. However, the data based on observation and documentation was repeated. So, the data collected by the researcher was enough.

First, for D class, based on the finding of the observation on April $26^{\text {th }}, 2016$, the researcher found that the English teacher used question-answer display and translation as teaching techniques. The English teacher also used visual media and multimedia as teaching media. Visual media used by the English teacher was whiteboard while multimedia used by the English teacher was power point. Questionanswer display combined with power point and whiteboard. It was used to describe characteristics of people and things around, while translation was used to translate some difficult words. In using those techniques and media, all of the students paid attention to the English teacher.

Second, for E class, based on the finding of the observation on April $26^{\text {th }}$,
2016, the researcher found that the English teacher used question-answer display and translation as teaching techniques. The English teacher also used textbook as teaching media. Question-answer combined with the textbook, namely Bupena. It was used to describe characteristics of things around. The English teacher used translation technique to translation some difficult words. The English teacher asked the students about the meaning of some words. The responses of students were also good. They were all showing good response during teaching and learning process.

Third, for E class, based on the finding of the observation on April 27 $7^{\text {th }}$, 2016, the researcher found that the English teacher used question-answer, translation, and discussion as teaching techniques. The English teacher also used human media and printed media as teaching media. Questionanswer display used with the material about describing people and describing things around. It is combined with printed media. Printed media used by the English teacher was textbook, namely Bupena. The responses of the students were good. Translation technique used with the material about describing people and describing things around. It was combined with human media. The responses of the students were also very good. For discussion technique, the teacher asked the students to make a group. The group consisted of two persons in a group. The teacher asked the students to make ten questions and ten answers. All of the students were showing good response.

Fourth, for D class, based on the finding of the observation on May $3^{\text {rd }}$, 2016, the researcher found that the English teacher used question-answer display, translation, and drilling as teaching techniques. The English teacher also used human media, printed media, and visual media as teaching media. The English teacher used question-answer display and drilling as teaching techniques. Questionanswer display combined with human 
media and whiteboard. The teacher gave some questions about animal. Translation technique combined with the textbook. The English teacher asked the students about the meaning of animal and the behaviour of the animal. Drilling technique was also combined with textbook. All of the students were showing good response during English teaching process conducted by the teacher using those techniques and media.

Fifth, for E class, based on the finding of the observation on May $3^{\text {rd }}, 2016$, it was found that the English teacher used question-answer display, translation, human media, and visual media. In the action, the teacher gave some questions some words about animal such as part of the body of the animal and behaviour of the animal. In using question-answer display, all of the students showed good responses. Translation combined with visual media, namely whiteboard. The English teacher translated some words about part of the body of the animal. In using translation technique, all of the students showed good responses.

Sixth, for D class, based on the finding of the observation on May $13^{\text {th }}$, 2016, the researcher found that the English teacher used question-answer display, translation, human media, and printed media. The English teacher used questionanswer display by giving some questions about behaviour of the animal. Questionanswer display was combined with human media and textbook, namely Bupena. The English teacher also used translation by translating some words about behaviour of the animal. In implementing those techniques and media, most of the students looked interested during English teaching process.

Seventh, for A class, based on the finding of the observation on May $13^{\text {th }}$, 2016, the researcher found that the English teacher used question-answer display, translation, human media, and printed media. The English teacher used questionanswer display by giving some question about the characteristics of the animal. Question-answer display was combined with textbook. The English teacher also used translation technique by translating some words about animal and public signs. Translation technique combined with human media. In implementing those techniques and media, there were 17 students looked interested and three students did not pay attention.

Eighth, for B class, based on the finding of the observation on May $16^{\text {th }}$, 2016, the researcher found that the teacher used question-answer display and translation as teaching technique. The English teacher used human media as teaching media. The English teacher combined human media with question answer display and translation. In implementing question-answer display, the English teacher asked the students to mention name of animal, characteristics of the animal, and also the name of the public signs or symbols orally. In using translation technique, the English teacher gave some words about animals and public sign orally then the students translated them in Bahasa orally. In implementing those technique and media, there were 17 students looked interested and four students often talked together with their friends.

Ninth, for $\mathrm{C}$ class, the researcher found that the English teacher used question-answer display, drilling, and translation. The English teacher also used human media, printed media, and whiteboard as teaching media. The English teacher combined human media and whiteboard as visual media with question answer display. In implementing questionanswer display, the English teacher asked the students to mention name of animal, characteristics of the animal, and also the name of the public signs or symbols orally. In implementing translation technique, the teacher gave some words about animal and sign orally then the students translated it in Bahasa orally. In implementing drilling technique, the English teacher only used 
drilling technique in one topic that was describing animal. From those processes, the researcher found that there were 18 students and all of the students paid attention to the English teacher and teacher's instruction. All of them joined in English teaching process.

\section{Discussion on Teaching Technique}

From the findings, it can be seen that the English teacher mostly used questionanswer display and translation. The English teacher used those techniques at every class of the seventh graders. Based on Crooks and Chaudron's theory, question-answer display and translation is included in controlled category. Controlled category is a basic teacher centered, the teacher as main role. For question-answer display, Crookes and Chaudron (1991) stated that questionanswer display is an activity involving encouraging of student responses based the material explained before. Question-answer display is not an open question. This is similar to what the English teacher had done in the classroom. The English teacher gave questions which have definite answer.

For translation technique, Crookes and Chaudron (1991) also said that translation technique is a technique that used by the teachers by combining first language with the second or foreign language. The teachers translate the language from foreign language to students' first language or from the first language to students' foreign language. Based on the findings, the English teacher mostly translated the language from foreign language to the first language.

The findings also showed that the other techniques used by the English teacher were drilling and discussions. For drilling, drilling technique is also part of controlled category. Crookes and Chaudron (1991) stated that drilling is a technique that used by the teacher to make the students understand how to say the words correctly by combining with repetition. In this case, the teacher used drilling technique after the teacher explained the material. For discussions technique, it is included in free category. Crookes and Chaudron (1991) stated that discussion is a debate or other form of grouped discussion based on specified topic. Quite similar with Crooks and Chaudron, Kayi (2006) also stated that discussion is a technique that letting the students to find solution or share their idea on given topic in a form of group.

\section{Discussion on Teaching Media}

From the findings, it can be seen that the English teacher mostly used human media, and printed media. The English teacher used those media at every class of the seventh graders. For human media, the English teacher used herself as media. The English teacher used herself as media to get interactive learning. Besides, the English teacher can also pay attention to students as much as possible. For printed media, the teacher always used textbook as printed media. The textbook used by the English teacher was Bupena. The teacher used Bupena because that book provides material that related with real life situation and easy to understand. The other media used by the English teacher in teaching speaking were multimedia and visual media. For visual media, the teacher used whiteboard as visual media. For multimedia, the English teacher used power point as multimedia. Andresen and Van Den Brink (2013) stated that the characteristic of multimedia contains texts, graphics, animations, video and sound in an integrated way and the content can be presented differently. In this case, the students always paid attention to the teacher. However, all of those media combined by the English teacher with various techniques.

\section{CONCLUSION}

Based on the finding and discussions, the researcher is able to make conclusion by answering research problems. The first is teaching techniques used by the teacher in 
teaching speaking. The second is the teaching media used by teacher used by the teacher in teaching speaking.

The first conclusion is about teaching techniques used by the teacher in teaching speaking at the seventh grade students. The researcher concludes that the teacher used various techniques in teaching speaking at the seventh grade students. The techniques used by the teacher were question-answer display, translation, drilling, and discussion. Techniques used by the teacher are good and appropriate because it can make students interested in teaching and learning process especially in speaking.

The second conclusion is about teaching media used by the teacher in teaching speaking at the seventh grade students. The researcher also concludes that the teacher used various media as teaching media in teaching speaking at the seventh grade students. The media used by the teacher were human media, printed media, visual media, and multimedia. Most of the media used by the teacher were interesting and can make the students engaged with teaching speaking process.

However, there are also some weaknesses of this research, such as the amount of the classroom observation in each class (A-E class) was imbalance and the limited number of the students who became the object of the interview. Therefore, this research will be better if the researcher increases the amount of observation and interview.

\section{REFERENCES}

Andresen, B. B., \& Van Den Brink, K. (2013). Multimedia in Education Curriculum. Moscow: UNESCO Institute for Information Technologies in Education. Retrieved from http://unesdoc.unesco.org/images/0022 /002241/224187e.pdf

Arsyad, A. (2015). Media Pembelajaran
(Edisi Revisi). Jakarta: Rajawali Pers.

Bertram, C., Ranby, P., Adendorff, M., Reed, Y., \& Roberts, N. (2010). Using Media in Teaching. (J. Gultig, Ed.). Braamfontein: Saide. Retrieved from http://www.oerafrica.org/system/files/ 10734/umitintoductorysection.pdf?file $=1 \&$ type $=$ node $\&$ id $=10$ $734 \&$ force $=$

Crookes, G., \& Chaudron, C. (1991). Guidelines for Classroom Language Teaching. In M. Celce Murcia (Ed.), Teaching English as a Second or Foreign Language (pp. 46-67). Rowley: Newbury House. Retrieved from http://sls.hawaii.edu/Gblog/wpcontent/uploads/2011/08/CrookesChaudron-1991.pdf

Indriyani. (2015). Method of teaching speaking to the seventh grade of SMP Muhammadiyah 2 Surakarta 2014/2015 academic year (Skripsi). Universitas Muhammadiyah Surakarta, Surakarta.

Kayi, H. (2006). Teaching Speaking: Activities to Promote Speaking in a Second Language. The Internet TESL Journal, 12(11). Retrieved from http://iteslj.org/Techniques/KayiTeachingSpeaking.html

Khameis, M. (2006). Using Creative Strategies to Promote Students' Speaking Skills. Retrieved November 23, 2015, from https://pdfs.semanticscholar.org/db20/ 77eadb2b09ce5952ff95e59f825308d6 9d65.pdf

Miles, M. B., \& Huberman, M. A. (1994). Qualitative Data Analysis. United States of America: Sage Publications.

Nurhayati, L. R. (2012). Peranan Guru dalam Meningkatkan Kemampuan Berbicara Siswa pada Pembelajaran Bahasa Inggris Materi "Things in the Classroom” Melalui Spelling Games (Skripsi). Institut Agama Islam Negeri 
Syekh Nurjati Cirebon, Cirebon.

Pradana, M. I. (2012). Interaksi sosial pada Anak Periode Late Childhood yang Bekerja (Skripsi). Universitas Gunadharma, Jakarta.

Reed, J. (2003). Teaching Techniques. Retrieved November 23, 2015, from http://www.tiac.net/ mabaker/Teachin g_Techniques(06-0326)(Reformatted10-12-23).pdf

Sugiyono. (2014). Memahami Penelitian Kualitatif. Bandung: Alfabeta. 